\title{
Typeren op niveau
}

Citation for published version (APA):

van den Berg-Loonen, E. M. (2001). Typeren op niveau. Maastricht University. https://doi.org/10.26481/spe.20010316eb

Document status and date:

Published: 16/03/2001

DOI:

10.26481/spe.20010316eb

Document Version:

Publisher's PDF, also known as Version of record

\section{Please check the document version of this publication:}

- A submitted manuscript is the version of the article upon submission and before peer-review. There can be important differences between the submitted version and the official published version of record.

People interested in the research are advised to contact the author for the final version of the publication, or visit the DOI to the publisher's website.

- The final author version and the galley proof are versions of the publication after peer review.

- The final published version features the final layout of the paper including the volume, issue and page numbers.

Link to publication

\footnotetext{
General rights rights.

- You may freely distribute the URL identifying the publication in the public portal. please follow below link for the End User Agreement:

www.umlib.nl/taverne-license

Take down policy

If you believe that this document breaches copyright please contact us at:

repository@maastrichtuniversity.nl

providing details and we will investigate your claim.
}

Copyright and moral rights for the publications made accessible in the public portal are retained by the authors and/or other copyright owners and it is a condition of accessing publications that users recognise and abide by the legal requirements associated with these

- Users may download and print one copy of any publication from the public portal for the purpose of private study or research.

- You may not further distribute the material or use it for any profit-making activity or commercial gain

If the publication is distributed under the terms of Article $25 \mathrm{fa}$ of the Dutch Copyright Act, indicated by the "Taverne" license above, 
Ella M. van den Berg-Loonen

Typeren $\mid$ op $\mid$ niveau 
(C) Dr. E.M. van den Berg-Loonen, Maastricht 2001 Vormgeving en druk: Wijntjens Druk Maastricht 


\section{Typeren op niveau}

Rede uitgesproken bij de aanvaarding van het ambt van bijzonder hoogleraar in de Histocompatibiliteit en Immunogenetica van Transplantatie aan de Universiteit Maastricht op 16 maart 2001

Dr. Ella M. van den Berg-Loonen 



\section{Mijnheer de Rector Magnificus,}

Zeer gewaardeerde toehoorders,

Een orator wordt geacht zijn of haar respect door vakgenoten al te hebben verworven en dus moet zijn of haar oratie in eerste instantie gericht zijn op niet-vakgenoten. Dat valt niet mee, als je leeropdracht begint met het woord histocompatibiliteit. In het woord histocompatibiliteit vallen de delen histo, weefsel, en compatibiliteit, overeenstemming, te herkennen. Als beide delen worden verbonden met orgaan- en beenmergtransplantatie wordt het mogelijk duidelijker. Bij deze transplantaties worden organen of beenmergcellen van de ene gezonde persoon overgebracht naar een andere, zieke. De gezonde persoon geeft, doneert, en is daarmee de donor, terwijl de niet-gezonde krijgt en dus de ontvanger is. Wanneer organen of beenmerg getransplanteerd worden, wordt in feite weefsel van de donor naar de ontvanger overgebracht. Op dat weefsel nu, zijn bepaalde structuren te herkennen, met name op het oppervlak van de cellen waaruit dat weefsel bestaat. Hoe beter donor en ontvanger overeen komen met betrekking tot die structuren, hoe beter het transplantaat aanslaat en overleeft. Mlet andere woorden, er moet een zekere mate van weefselovereenstemming, histocompatibiliteit, bestaan om tot succesvolle transplantatie te komen.

Wat precies zijn die celoppervlaktestructuren, die een rol spelen bij transplantatie? Ze zijn misschien het best te omschrijven als een soort bloedgroepen. ledereen kent het $A B O$ bloedgroepsysteem met de vier groepen, $A, B, O$ en $A B$, die zo belangrijk zijn bij 
transfusie van met name rode bloedcellen. De bloedgroepen waar we hier over spreken, zijn groepen die voorkomen op witte bloedcellen. Ze behoren tot het zogenaamde HLA systeem en zijn oneindig veel ingewikkelder dan die van de rode cellen. HLA is een afkorting die gebruikt wordt voor Humane Leucocyten Antigenen. Die antigenen zijn eiwitten die voorkomen op de leucocyten, de witte bloedcellen. Het HLA systeem is waarschijnlijk het meest ingewikkelde systeem dat we kennen bij de mens, en het bestaat uit een aantal verschillende genen.

Wat verstaan we onder genen? Een gen is een biologische eenheid van overerving met een bepaalde plaats op het chromosoom. Die eenheid heeft een effect op het fenotype, hij kan veranderen door mutatie en kan gecombineerd worden met andere eenheden. De HLA genen zijn zulke biologische eenheden en hebben een bepaalde plaats op het chromosoom. Ze liggen op chromosoom 6 , zoals dat in 1977 door ons werd beschreven. Ze hebben een effect op het fenotype en zijn in de loop der tijden veranderd door mutatie. Elk gen kan zich presenteren in verschillende vormen en dat geldt zeker voor het HLA systeem. Het is de vorm van het gen die bepaalt welk antigeen op de celwand tot uiting komt. Omdat het hier meerdere genen betreft, is het aantal verschillende combinaties dat mogelijk is, enorm. De kans dat één van $u$ in deze zaal, wat betreft HLA, identiek is aan iemand anders, is uiterst gering. Geschat wordt dat de kans op HLA identiciteit tussen onverwante personen minder dan 1 op een miljoen is.

HLA antigenen zijn erfelijk bepaald, een mens wordt ermee geboren 
en gaat ermee dood. Hij krijgt de helft van de kenmerken van elke ouder en daarom worden binnen families wel identieke personen gevonden. Tussen broers en zussen is de kans om hetzelfde HLA type te hebben $25 \%$, zij hebben in zulke gevallen dezelfde genetische informatie van hun ouders gekregen. Dat nu is het stuk genetica uit het tweede deel van mijn leeropdracht. Het heet immunogenetica omdat erfelijk bepaalde polymorfismen worden bestudeerd, die worden aangetoond met immunologische methoden. In deze rede wil ik proberen, dit vakgebied voor $u$ te verduidelijken, met name die aspecten waar wij ons in Maastricht mee bezighouden. Als inleiding zal ik kort de historie van het HLA systeem belichten, daarna ingaan op de moleculair biologische ontwikkelingen van de afgelopen 10 jaar en tenslotte de ontwikkelingen met betrekking tot de kliniek belichten, zowel wat betreft transplantatie alsmede associatie met ziekten. 


\section{Immunogenetica en het HLA systeem}

Het vakgebied van de immunogenetica is een goede eeuw oud. Karl Landsteiner beschouwen we als de peetvader van de immunogenetica, omdat hij in 1900 de ABO bloedgroepen ontdekte en hun belang voor transfusie aantoonde. Wanneer bloed van individuen met verschillende bloedgroepen bij elkaar werd gebracht, werd een transfusiereactie gezien. Onder het microscoop was zichtbaar dat de rode bloedcellen klonterden. Bij transfusie met gelijke bloedgroepen gebeurde er niets. De transfusiereactie is het gevolg van afweerstoffen die in het bloed van ieder mens aanwezig zijn, zogenaamde antistoffen.

Pas veel later, in de jaren '50, blijken ook antistoffen voor te komen tegen witte bloedcellen. Jean Dausset beschreef het voorkomen van zulke antistoffen in patiënten die veel transfusies hadden gehad. Hij voerde geplande transfusies uit. Hij gaf vrijwilligers bloed en onderzocht hen daarna op de vorming van antistoffen. Het eerste HLA antigeen dat zo werd vastgesteld werd MAC genoemd en vele jaren later zou Dausset voor zijn werk de Nobelprijs krijgen. Maar de testen waren weinig reproduceerbaar, de sera zwak, en de wetenschappelijke goegemeente bleef sceptisch. Dan beschrijuen Jon van Rood en Rose Payne beiden, dat ook zwangerschap kan leiden tot de vorming van antistoffer tegen witte bloedcellen. Zwangerschap kan beschouwd worden als een soort transplantie, het ongeboren kind heeft de helft van zijn genetisch materiaal van de vader gekregen en dat deel is dus vreemd voor de moeder. Sommige moeders maken 
tijdens de zwangerschap antistoffen gericht tegen de witte bloedgroepen, die het kind van de vader heeft gekregen. Meestal verdwijnen deze antistoffen weer na enkele maanden, maar om onbekende redenen blijven sommige vrouwen antistoffen produceren, zelfs nog na jaren. Daar maken we graag gebruik van door hun sera te verzamelen en te gebruiken voor onze HLA typeringen. Hierdoor en door vele technische verbeteringen werden de testen betrouwbaarder en werd het bestaan van de HLA antigenen een vaststaand feit.

Vanaf dat moment, eind jaren ' 50 , begin jaren ' 60 , worden internationale workshops georganiseerd. Deze workshops zijn van immens belang geweest voor de ontwikkeling van de kennis van het HLA systeem en het chromosomale gebied waartoe het behoort, het MHC. MHC is de afkorting van Major Histocompatibility Complex. Het ligt op de korte arm van chromosoom 6 en wordt zo genoemd omdat het velle genen bevat, waaronder een aantal die belangrijk zilin bij het afstoten van een transplantaat. De workshops hebben zich steeds op een bepaald thema gericht, waardoor grote collaboratieve experimenten ontstonden. Eén van de eerste workshops was die in Turijn in 1967, waarbij familieonderzoek centraal stond. De sera die daarvoor gebruikt werden, moesten eenduidige en enkelvoudige reactiviteit bezitten en dienden daartoe geadsorbeerd te worden met vele cellen. Dat monnikenwerk werd verricht door mijn promotor Paul Engelfriet. Op deze wijze kon worden aangetoond dat HLA antigenen overerven volgens de wetten van Mendel en codominant zijn, dat wil zeggen dat zowel de vaderlijke als de moederlijke overgeërfde antigenen zichtbaar 
zijn op de cel. Ook werd duidelijk dat er grote verschillen bestaan tussen de frequenties waarin deze antigenen voorkomen in de verschillende rassen.

De vijfde workshop die werd gehouden, vond plaats in thet Franse Evian en was helemaal gewijd aan populatieonderzoek. Het was 1972 en voor mij mijn eerste workshop. Tot in alle uithoeken van de wereld hadden HLA onderzoekers bloed verzameld. HLA antigenen werden bepaald bij bosjesmannen, Hottentotten, Paaseilanders en eskimo's. Wij, en dat waren wij in Amsterdam, bepaalden de HLA antigenen bij een groep Zuid-Moltukkers en haalden dat bloed tamelijk prozailsch, uit Vught, waar een grote Molukse gemeenschap gevestigd was. Maar sommige onderzoekers verrichtten echt veldwerk en typeerden in de rimboe en op exotische eilanden. De gegevens werden gebundeld en door populatiegenetici geanalyseerd. Inwoners van Lapland hadden meer gemeen met Centraal-Europese zigeuners dan met hun Finse en Zweedse zuiderburen. De populatie van Sardiniẻ bleek verdeeld in laag-en hooglanders met heel verschillende kenmerken, die parallel liepen aan de gevoeligheid voor malaria. Chinezen bleken antigenen te bezitten die exclusief voor hun ras zijn, zo ook de Europeanen, die tot het blanke ras behoren. Sporadisch werd wel eens een exclusief blank antigeen in de Chinese populatie aangetoond, maar dit werd beschouwd als het gevolg van gemorste genen in den verre. De verschillen in voorkomen van de verschillende antigenen, zijn het gevolg van mutatie en selectie. Was in de eerste workshops het aantal deelnemende labs beperkt, rond de 40 labs in 1972 , daarna 
nam het aantal snel toe tot 400 labs in de laatste in 1996. Deze gezamenlijke inspanningen hebben de HLA wereld veel nuttige informatie verschaft en het heeft reagentia en technieken door de hele wereld in hun juiste context gezet. Aan de workshops werd de nomenclatuur gekoppeld, middels de WHO nomenclatuur commissie, die na elke workshop nieuwe antigenen en later allelen van een naam voorzag. De eenduidige nomenclatuur heeft wereldwijd respect afgedwongen en heeft model gestaan voor vele andere aspecten van humaan genetische nomenclatuur. Als een aantal belangrijke spelers in een veld besluiten samen te werken, kunnen anderen zich eigenlijk niet permitteren om niet mee te doen. Uitgangspunt moet dan wel zijn dat het doel van zo'n samenwerking iets is, dat onmogelijk door een enkele speler kan worden bereikt.

En dat de winst voor iedere deelnemer, in verhouding staat tot zijn lasten. Dat was zeker in de jaren '70 en ' 80 het geval, de laatste jaren wordt dit evenwel steeds minder. De workshops lijken hun beste tijd te hebben gehad en hun toekomst is dan ook een onzekere zaak. 


\section{Moleculair biologische technieken en het HLA systeem}

Al decennialang worden HLA typeringen uitgevoerd met behulp van serologische technieken. Dat wil zeggen dat men de antigenen, de eiwitten op het celoppervlak, laat reageren met speciaal daarvoor geselecteerde antistoffen, antisera zoals we die noemen. Vervolgens worden uit de reacties, die onder een microscoop worden afgelezen, conclusies getrokken. De cellen leven nog, de reactie is negatief of de cellen zijn dood, de reactie is positief. Een tijd lang zijn ook cellulaire technieken in zwang geweest, om de aanwezigheid van bepaalde antigenen aan te tonen. Beide technieken hadden en hebben zo hun bezwaren. Beide zijn sterk afhankelijk van de kwaliteit van de cellen, die gebruikt worden voor de test. Dat betekent dat het afgenomen bloed met speciale voorzorgen en altijd binnen korte tijd, op de plaats van typering moet arriveren. De test die vele uren in beslag neemt, moet snel daarna worden uitgevoerd. De serologische HLA typering is een moeilijke techniek, die veel ervaring vereist van de uitvoerende analisten. Ze levert per definitie een uitslag op het serologisch resolutie niveau, iemand is $A 1$ of $A 2$ of $A 3$. We noemen dit ook wel het lage resolutie niveau. Lange tijd was het onmogelijk om hier iets aan te veranderen.

Maar in het midden van de jaren " 80 kwam er toch verandering. met de introductie van moleculair biologische technieken. Niet langer werd het eigenlijke HLA antigeen aangetoond, maar de erfelijke informatie ervoor, zoals die is opgeslagen in het DNA. De mogelijkheid werd gecreëerd, om de hoeveelheid DNA, 
waamee gewerkt moet worden, gevoelig te verhogen en wel precies dat deel, waarin de onderzoeker is geinteresseerd. Dit werd mogelijk door de polymerase chain reactie, kortweg de PCP genoemd. Onder speciaal gekozen omstandigheden verdubbelt de PCR reactie het test DNA in een tijdsbestek van enkele minuten. Door de reactie keer op keer te herhalen wordt het DNA exponentieel vermeerderd. Twee strengen worden er vier, worden er acht, worden er 16. Na 30 cycli zijn in theorie ca 1 miljard kopieën gemaakt en het is dan ook geen probleem om zeer schaars DNA via een PCR te detecteren.

Gebaseerd op de PCR reactie werden verschillende DNA typeermethoden ontwikkeld. Met behulp van deze technieken werd al snel duidelijk, dat de serologische groepen die we tot nu toe hadden aangetoond, veel gecompliceerder waren dan aanvankelijk werd verondersteld. Antigenen zoals bijwoorbeeld A1, bliken wit veel verschillende subtypen te kunnen bestaan. Deze noemen we allelen. Van het veel voorkomende antigeen A2 zijn inmiddels meer dan 50 varianten bekend.

Toen wij in Maastricht in 1993 met DNA typeringen starten, stonden we voor de keuze welke van de beschikbare techrieken te kiezen. Elke methode heeft zijn eigen voor- en nadelen. Voor ons was een woorwaarde, dat de gekozen techniek snel moest zijn, tenminste zo snel als de serologische typering, zodat hij bruikbaar zou zijn voor nachtelijke orgaandonortypering. Daarnaast was een techniek gewenst, die ook voor de subtypetypering een ondubbelzinnig antwoord gaf. De voortdurende 
toename van het aantal allelen maakt, dat de praktische uitvoerbaarheid van een aantal technieken, althans voor de subtypebepaling, ondoenlijk is. In feite is voor dit hoge resolutie niveau alleen de methode die als SBT, Sequence Based Typing bekend staat, geschikt. Het nadeel ervan is, dat een bepaling tenminste 2 dagen duurt. Daarom is een beperking tot SBT ook niet echt een mogelijkheid. Een combinatie van twee technieken lijkt de meest reëele optie in een hedendaags laboratorium voor weefseltypering.

Wat is precies Sequence Based Typing? Het is de mogelijkheid om een HLA typering te verrichten, door het bepalen van de bouwsteenvolgorde van een klein stukje DNA. Door de beschikbaarheid van automatische DNA sequencers werd de bepaling van een sequentie mogelijk. Met behulp van intelligente software kan analyse van de gevonden sequentie verricht worden, waardoor de mogelijkheid tot het vaststellen van een HLA-typering ontstaat. In principe wordt van een PCR product, dat uit dubbelstrengs DNA bestaat, enkelstrengs DNA gemaakt. Door het toevoegen van bepaalde reagentia wordt de aanmaak van nieuw DNA bevorderd. Het mengsel wordt verdeeld in 4 delen en aan elk deel wordt een stof toegevoegd, die ervoor zorgt dat de DNA aanmaak stopt. Die stof is voor elk van de 4 delen verschillend. In elk reactiemengsel eindigen zo de gevormde DNA fragmenten op hetzelfde nucleotide, dezelfde bouwsteen. Op die manier wordt een set van gedeeltelijke replica's opgebouwd, die allemaal starten met dezelfde positie, maar eindigen op verschillende punten langs de DNA keten. Door de juiste con- 
dities te kiezen worden de verschillende producten op random wijze aangemaakt. Als deze DNA fragmenten in een elektrisch veld worden gebracht door ze te verdelen over 4 lanen op een gel, bewegen zij zich daarin afhankelijk van hun grootte. Aan de hand hiervan kan de sequentie gelezen worden. Door de resultaten van de 4 corresponderende lanen, weergegeven in 4 verschillende keuren, te combineren, ontstaat een sequentie en met behulp van speciale software kan uiteindelijk het meest waarschijniljke HLA vpe worden voorgesteld.

De HLA genen zijn van twee typen, de klasse 1 en de klasse 2 genen. De klasse 1 genen heten $A, B$ en $C$, zij coderen voor de eiwitten, die later op de cel de HLA ABC-antigenen vormen. Ze komen voor op vrijwel alle kernhoudende cellen in het lichaam. De klasse 2 genen zijn DR, DQ en DP, en de producten hiervan ziln de HLA DR-, DQ- en DP-antigenen. Ze hebben een veel geringere verspreiding, ze komen voorall voor op cellen, die bij immuunreacties betrokken zijn.

Alle HLA antigenen bestaan uit 2 eiwitketens. De klasse 1 antigenen bestaan uit een lange eiwitketen afkomstig uit de MHC regio, die verdeeld is in 3 domeinen met daaraan een transmembraneuze staart. Die keten wordt gecombineerd met een tweede eiwitketen, het beta-2-microglobuline, dat echter van een heel ander chromosoom afkomstig is. Ook de klasse 2 antigenen bestaan uit 2 eiwitketens, maar die worden wel alle twee gecocieerd door de MHC regio. De gecombineerde ketens vormen het functionele HLA antigeen, dat we zien op de celwand 
en dat dus het product is van een of meerdere genen in het MHC gebied. Door variatie in de volgorde van de bouwstenen van die genen zijn de antigenen die we uiteindelijk zien, verschillend. Die verschillende verschijningsvormen noemen we allelen.

De verschillen tussen de allelen zijn grotendeels geconcentreerd in bepaalde delen van het gen. Elk gen bestaat uit exonen en intronen. De exonen zijn de gebieden die vertaald worden en gebruikt bij de samenstelling van het eiwitproduct, de intronen worden niet vertaald. De HLA klasse 2 genen bestaan uit 6 exonen en de klasse 1 uit 8 . Voor de klasse 2 allelen vinden we de meeste verschillen in het gebied, dat exon 2 genoemd wordt. Daardoor kan de klasse 2 typering van de meeste mensen beperkt worden tot de bepaling van de sequentie van exon 2 . Voor de klasse 1 genen zijn 2 exonen polymorf, de exonen 2 en 3. Dat wil zeggen, dat beide exonen op hun sequentie moeten worden onderzocht om de typering van het individu vast te stellen.

Vandaag de dag is er een indrukwekkend aantal HLA allelen bekend. Dat heeft alles te maken met het niveau waarop we de alielen aantonen. Noemden we vroeger $\mathrm{A} 1$ en $\mathrm{A} 2$ allelen van elkaar, omdat we alleen serologisch, dus op het laagste resolutieniveau, konden vergelijken, nu kan A2 heel goed een allel van zichzelf zijn, omdat de bepalingen op het hoge resolutie niveau plaats vinden. Het aantal groeit snel en elke poging om precieze aantallen te geven is in feite direct obsoleet. Per jaar komen er gemiddeld 180 nieuwe allelen bij, en het zal duidelijk zijn, dat de uitbreiding zich afspeelt op het niveau van de hoge 
resolutie. Het aantal verschillende allelen van de 6 HLA genen bedroeg op 1 januari van dit jaar 1340. Van die 1340 zijn er 790 klasse 1 allelen en 550 klasse 2 allelen.

De methodes om te sequencen voor de verschillende HLA genen werden door mijn medewerkster Christien Voorter en haar groep beschreven voor de genen DR, DQ, B en C. Inmiddels zijn door hen 36 nieuwe allelen gedefinieerd, vele allelen bevestigd en werden bijdragen geleverd aan de sequenties in andere exonen van een groot aantal allelen. Bij het gen HLA-C bleek de variabiliteit naast exon 2 en 3 ook in de minder polymorfe exonen groter dan verwacht. Op dit moment houdt Wen Swelsen zich bezig met de variabiliteit van de genen $A$ en $B$, zowel in de verschillende exonen alsook in de intronen. 


\section{Biologische betekenis van HLA-moleculen}

Door het effect dat het HLA systeem heeft op transplantatie werd het onderzoek naar de transplantatieantigenen, zoals de HLA antigenen ook wel worden genoemd, gestimuleerd. Pas veel later werd de biologische betekenis van de $\mathrm{MHC}$ moleculen ontdekt. Het is duidelijk dat het lichaam om zichzelf intact te houden, onderscheid moet kunnen maken tussen zaken die eigen, en zaken die lichaamsvreemd zijn. De aanval van een ziekteverwekker moet worden afgeweerd, maar het eigen lichaam moet daarbij intact worden gelaten. Dat is nogal een klus, gezien de enorme variëteit aan ziekteverwekkers, zoals bacteriën, schimmels en virussen. Doordat het afweersysteem gebruik maakt van verschillende soorten cellen, namelijk $T$ of $B$ cellen in combinatie met de gespecialiseerde MHC producten, is het in staat deze moeilijke taak te volbrengen.

De wijze waarop een ziekteverwekker wordt herkend door B en $T$ cellen is heel verschillend. Een geactiveerde $B$ cel groeit uit tot een zogenaamde plasmacel, die antistofmoleculen gaat produceren. De antistoffen binden direct aan de ziekteverwekker en neutraliseren hem op die wijze. T cellen daarentegen, moeten om hun functie uit te oefenen een interactie met andere cellen aangaan, zij reguleren de activiteit van andere immuuncellen. Het pathogeen wordt in stukken gebroken en door een antigeen presenterende cel aan het immuunsysteem aangeboden. Dit gebeurt door de HLA moleculen op het oppervlak van de cel, wiens taak het is om eiwitten te presenteren aan $T$ cellen. De $T$ 
cell is niet in staat om die eiwitten direct te herkennen, maar kan dat alleen in de vorm van korte stukjes, die gebonden zijn aan HLA moleculen. Eiwitten in combinatie met een HLA molecuul zijn dus in staat de $T$ cel tot activiteit aan te zetten, terwijl geen van beide daartoe op zichzelf in staat is. 


\section{Transplantatie: immunisatie, afstoting en afstotingsbehandeling}

Hoe welkom de afweerreactie van het lichaam ook is, als het ziekteverwekkers betreft, zoveel minder gelukkig zijn we ermee, als het transplantatie betreft. Als cellen, weefsels of organen worden getransplanteerd tussen individuen met verschillende HLA groepen, worden ze als vreemd ervaren en reageert het afweersysteem van de ontvanger ook met een afweerreactie. Deze zogenaamde immuunrespons bedreigt de overleving van het transplantaat, maar ook die van de patiënt.

Er zijn twee manieren om deze reactie te voorkomen of in elk geval het effect ervan zo gering mogelijk te maken. De ene manier is niet specifiek, de andere wel.

(1) De niet-specifieke manier bestaat uit het toedienen van afweeronderdrukkende middelen. Maar het toedienen van deze middelen tast ook het vermogen aan om op infecties te reageren, en het verhoogt de kans op kanker. Na transplantatie wordt dan ook regelmatig kanker gezien, het meest in landen waar de dosering van de afweeronderdrukkende middelen hoog is.

(2) De specifieke manier om afstoting te voorkomen, is te zorgen dat het immuunsysteem niet of nauwelijks reageert, door donor en ontvanger zo goed mogelijk met elkaar overeen te laten komen wat betreft hun HLA antigenen. We noemen dat matchen voor HLA. Het risico op afstoting wordt verkleind, terwijl het vermogen om op infecties en kanker te reageren behouden bijift. Gebruikelijk worden beide strategieën gecombineerd en gezamenlijk hebben zij ertoe geleid dat transplantatie nu een routinebehandeling voor nierfalen kan worden genoemd. 
Bij het matchen van patiènt en donor kunnen zich problemen voordoen. Problemen die veroorzaakt worden doordat de patient antistoffen tegen HLA antigenen bezit of gaat maken. In tegenstelling tot antistoffen gericht tegen ABO bloedgroepen, die min of meer van nature aanwezig zijn, wordt de productie van HLA antistoffen uitsluitend op gang gebracht na een stimulus als bijvoorbeeld zwangerschap, bloedtransfusie of een eerdere orgaantransplantatie. Antistoffen die zo ontstaan, brengen een afstotingsreactie teweeg, waardoor het transplantaat verloren kan gaan.

\section{Er zijn 3 soorten afstoting.}

(1) Als antistoffen gericht tegen de HLA groepen van het transplantaat aanwezig zijn op het moment van transplantatie, vindt de afstotingsreactie heel snel plaats, direct nadat de bloedvaten van patiënt en transplantaat chirurgisch verbonden ziin. Dit heet hyperacute afstoting. Er is geen methode om dit soort afstoting om te keren. Om het te vermijden worden donor en ontvanger gematched voor HLA en worden zogenaamde kruisproeven verricht. In een kruisproef wordt eigenlijk de toekomstige situatie in het lichaam nagebootst in het laboratorium. Als de kruisproef positief is, is de kans op hyperacute afstoting groot en zal er niet getransplanteerd worden. Hyperacute afstoting komt, dankzij het verrichten van deze kruisproeven, zelden meer voor.

(2) Bij patiënten, die geen antistoffen bezitten op het moment van transplantatie, kan toch afstoting plaatsvinden. Dat duurt meestal iets langer, een paar dagen tot enkele weken. We noemen 
dat acute afstoting. Meestal worden ook dan antistoffen aangetroffen. Het transplantaat zal niet gaan functioneren, tenzij extra afweeronderdrukkende middelen worden gegeven. Als die middelen speciaal de $T$ cellen aanpakken, of als tijdelijk een hogere dosis wordt gegeven, zijn dit soort afstotingsreacties gedeeltelijk omkeerbaar en dus te behandelen. Toch is de lange termijn prognose voor dit soort patiënten niet rooskleurig. (3) Tenslotte kennen we een late vorm van afstoting, de chronische rejectie. Deze wordt gezien maanden tot jaren na transplantatie. Men denkt dat chronische afstoting ook het gevolg is van antistoffen, maar het precieze mechanisme is onduidelijk. Er is tot nu toe geen manier om deze vorm van afstoting te voorkomen.

HLA antistoffen: aanwezigheid en specificiteit: Omdat het bezit van antistoffen tegen HLA, zo belangrijk is voor transplantatiepatiënten, wordt veel aandacht besteed aan het bepalen van de aanwezigheid ervan, alsmede de vaststelling van de specificiteit. Van iedere patiënt wordt elke 3 maanden een serummonster afgenomen en onderzocht op antistoffen. Tegelijkertijd wordt de eventuele specificiteit ervan vastgesteld. De meest gebruikte screeningsmethode is een serologische test, die in feite gelijk is aan de manier waarop een HLA typering wordt verricht. Op die wijze worden klasse 1 antistoffen, gericht tegen de $A B C$ antigenen, maar ook klasse 2 antistoffen, gericht tegen $D R / D Q$ aangetoond. Maar een uitslag is maar zo gevoelig als de test waarmee hij bepaald wordt en niet alle antistoffen worden met een en dezelfde methode aangetoond. Daarom wordt veel onderzoek verricht naar andere, meestal gevoeliger technieken. In ons 
laboratorium werden verschillende methoden bestudeerd door Maarten Christiaans. Hij vergeleek de uitslagen van twee screeningsmethoden met de klinische resultaten van de transplantaties. Daarvoor gebruikte hij de klassieke CDC en de ELISA techniek. Beide methoden hadden een goede correlatie met de transplantaatoverleving, maar geen goede correlatie met elkaar. Dat wil zeggen dat de ene methode niet zo maar door de andere vervangen kan worden. Wel kon geconcludeerd worden dat ze elkaar aanvulden.

Kruisproeven: Het onderzoek op antistoffen voor transplantatie geeft aan, of een patiênt een risico loopt op hyperacute afstoting. Maar als een patiënt antistoffen heeft, wil dat niet zeggen dat er nooit een geschikt transplantaat gevonden kan worden. Meestal heeft een patiënt antistoffen tegen een aantal HLA antigenen, maar niet tegen allemaal. De kunst is dus een transplantaat te vinden met antigenen, waartegen de betreffende patiënt geen antistoffen heeft. Dat wordt vastgesteld middeis de kruisproef, zoals die al eerder beschreven werd. Als de kruisproef negatief is, nemen we aan dat de patiënt geen antistoffen bezit tegen de HLA groepen van het donororgaan. Maar evenals voor het onderzoek op de aanwezigheid van antistoffen, geldt ook hier dat de uitslag maar zo gevoelig is als de test waarmee hij bepaald wordt. Soms wordt afstoting, zelfs hyperacuut, gezien, terwijl toch de kruisproef negatief was. Dat is de reden dat al jarenlang onderzoek wordt gedaan naar het soort kruisproef, dat de beste voorspellende waarde heeft met betrekking tot de transplantaatoverleving. In de jaren ' 80 toonden wij aan, dat 
positieve B cel kruisproeven alleen een nadelig effect hebben: als zij een duidelijke klasse 2 specificiteit bezitten. Als het autoantistoffen tegen $B$ cellen betreft of antistoffen zonder duidelijke klasse 2 specificiteit, wordt er geen negatief effect gezien.

Meer recent toonde Maarten Christiaans aan dat zeer gevoelige kruisproeven, zoals die met flowcytometrie gedaan worden, niet per se een betere correlatie met het klinisch beloop laten zien. Hier wordt zeer verschillend over gedacht met name door de Verenigde Staten en Europa. De Verenigde Staten hebben een voorkeur voor flowcytometrische kruisproeven, en claimen een duidelijke verbetering van de transplantaatoverleving. Toch laten de transplantaatoverlevingen in Europa en de Verenigde Staten geen duidelijke verschillen zien. Men neemt aan dat de aandacht die wij hier schenken aan de immunisatiehistorie en het bepalen van de specificiteit, maakt dat de meerwaarde van flowcytometrie bij ons niet zo duidelijk is. Als de antistofhistorie van een patiënt goed wordt gevolgd, zijn alle immunisaties gedocumenteerd en is bekend waar de problemen verwacht kunnen worden. Toch kon Maarten Christiaans ook een positief effect van flowcytometrische kruisproeven aantonen, niet zozeer in het traject voor transplantatie, alswel in het traject erna. Als de patiënt een stijging vertoonde van de kruisproefuitslag ten tijde van de transplantatie, naar de kruisproefuitslag na transplantatie, was dat een indicatie voor beginnende afstoting. Het onderzoek naar antistoffen voor en na transplantatie wordt nu voortgezet en ook de specificiteitsbepaling met behulp van flowcytometrie wordt hierin betrokken. 
De immunogenetische kenmerken van een patiënt samen met de aan- of afwezigheid van antistoffen, weerspiegelen zich in het verloop na de orgaantransplantatie. De kliniek maakt gebruik van deze laboratoriumresultaten door bijvoorbeeld aangepaste afweeronderdrukking te geven, afhankelijk van de HLA match en de aanwezigheid van antistoffen. Als de match goed is, bijvoorbeeld bij een DR identieke transplantatie, en er zijn geen antistoffen, volstaat de toediening van twee afweeronderdrukkende middelen. Is de match minder goed of zijn er antistoffen aanwezig dan zal in de regel gestart worden met drie van dergelijke middelen.

Het gebruik van steeds nieuwere vormen van afweeronderdrukking maakt dat organen toch getransplanteerd kunnen worden, ondanks een aantal HLA verschillen. Door het chronisch tekort aan donororganen, is het buitengewoon moeilijk om voor elke patiënt een HLA passend transplantaat te vinden. Niet iedereen kan een ideale match krijgen, maar door strakke uitwisselingsregels. binnen Eurotransplant kan toch voor $25 \%$ van de patiënten een goede tot zeer goede match gerealiseerd worden.

Dat laat onverlet dat ook andere dan matchingscriteria een rol spelen bij het selecteren van de uiteindelijke ontvanger. De kwaliteit van het getransplanteerde orgaan, met name de tijd dat het orgaan niet doorbloed was, heeft groot effect op de transplantaatoverleving. De tijd die verloopt tussen de uitname van het orgaan en de uiteindelijke transplantatie is belangrijk voor het klinisch verloop. Mede hierdoor is de belangstelling voor 
levende donatie gegroeid, zeker nu naast familietransplantatie ook de mogelijkheid tot partnertransplantatie meer en meer benut wordt.

Altijd is de voorwaarde voor transplantatie een negatieve kruisproef, de afwezigheid van antistoffen gericht tegen de donor. Zoals ik al eerder zei wordt antistofproductie gestimuleerd door zwangerschap, bloedtransfusie en transplantatie. De eerste stimulus is de meest frequente en treft maar de helft van de bevolking. Vrouwen hebben dan ook vaker antistoffen dan mannen, en mannen hebben daarom vaker een negatieve kruisproef. De kans op transplantatie is voor mannen en vrouwen niet gelijk. Het vereist perfecte screening, goede HLA matching en een deskundig weefseltypeerder om deze disbalans zoveel mogelijk te compenseren. 


\section{HLA en associatie met ziekten}

Kort wil ik een laatste onderwerp aansnijden, de associatie van het HLA systeem met ziekten. Voor sommige ziekten wordt bij patienten vaker een bepaald HLA antigeen aangetroffen, dan op grond van de frequentie in de populatie verwacht zou worden. Als de associatie hoog is, kan HLA zelfs als diagnostische merker worden ingezet, zoals dat het geval is bij bijvoorbeeld de ziekte van Bechterew en narcolepsie. In de loop van mijn carrière ben ik bij vele associatieonderzoeken betrokken geweest. Myasthenia gravis, morbus Hodgkin, multiple sclerose, rheumatoide arthritis, colitus ulcerosa, spondylitis ankylopoietica en herseninfarcten zijn er maar een paar. Op dit moment nemen wij nog steeds deel aan het onderzoek van Jingwu Zhang in Houston, naar multiple sclerose, verhoogde cytokineproductie en HLA. Ook bestaat een samenwerkingsverband met de groep van Cesare Saltini in Modena, Italië, naar de HLA merkers die verantwoordelijk zijn voor de overgang van berylliumgevoeligheid naar berylliosis, een chronische longziekte, die geassocieerd is met het HLA-DPB gen. Het associatieonderzoek naar de betekenis van HLA antigenen en de gevoeligheid voor multifactoriële ziektebeelden, zal in de komende tijd worden voortgezet naar wij hopen in samenwerking met de nieuwe hoogleraar populatiegenetica. 


\section{Tot slot}

In de zin van kwaliteit is voor elke klinische toepassing het hoogste typeerniveau vereist. We werken met genetische kenmerken, die gisteren, vandaag en morgen dezelfde zijn en overerven van ouder op kind. Daarbij past geen ongeveer. In de zin van oplossend vermogen kan het typeerniveau verschillen. Niet voor elke klinische toepassing is hetzelfde niveau vereist. Hoge resolutie typering en matching bij onverwante beenmergtransplantatie hebben een groot effect en het hoogste typeerniveau is hier dan ook noodzakelijk. Voor solide orgaantransplantatie is mogelijk en hopelijk een lagere resolutie voldoende, hoewel ook hier goede effecten van hoge resolutietypering beschreven zijn.

Aan het eind van deze rede gekomen, hoop ik dat ik $u$ een idee heb gegeven van de stand van zaken op mijn vakgebied, de immunogenetica van transplantatie. Het moge duidelijk zijn dat vele factoren het succes van een transplantatie beïnloeden, en dat de HLA moleculen hier een belangrijke rol in spelen. Het belang ervan, zeker op de lange termijn mag niet onderschat worden, maar helaas wint de korte termijn visie het nog wel eens. Ons onderzoek zal op de ingeslagen weg voortgezet worden, wat betreft moleculaire genetica, associatie met ziekten en de rol van humorale immuniteit bij transplantatie. Een hoog niveau zal op alle gebieden ons streven blijven, in letterlijke en figuurlijke zin. 


\section{Dankwoord}

Geen oratie zonder dankwoord, ook deze niet.

Mịnheer de Rector Magnificus, leden van het College van Bestuur en leden van het Bestuur van de Faculteit der Geneeskunde, $u$ allen wil ik bedanken voor mijn benoeming tot bijzonder hoogleraar in de immunogenetica van transplantatie. Het is een erkenning voor het vakgebied en ik beschouw het als een voorrecht om aan deze universiteit de elfde vrouwellike hoogleraar te zijn.

De Raad van Bestuur van het azM en de Stichting Annadal, die de leerstoel instelde, dank ik voor het in mij gestelde vertrouwen. Ik zal mij naar beste vermogen voor de topreferente zorg die transplantatie is, inzetten. De voorzitter van de Raad van Bestuur van het azM, Jan Carpay, dank ik in het bijzonder. Niet alleen voor zijn vrouwvriendelijk hooglerarenbeleid, maar vooral voor zijn inzet en open blik en de uren die wij aan de opbouw van de azM kunstcollectie besteedden.

Mijn scholing in dit vak heb ik in Amsterdam in het CLB opgedaan. Mijn beide promotores, Joghem van Loghem en Paul Engelfriet, dank ik voor de wijze waarop zij mij in de wereld van immunologie en transplantatie hebben ingewijd. Een bijzonder woord van dank past voor mijn kamergenoot en leermeester in de populatie genetische aspecten van HLA, Lourens Nijenhuis. Hij is helaas te vroeg overleden, maar hij leerde mij dat wat ik moest weten over frequenties, vaderschapsonderzoek en associatie- 
onderzoek. Meer dan enig ander was hij mijn genetische peetvader.

Op ieders carrièreweg komen dwarsliggers voor. Het zijn meestal niet degenen die men wil bedanken. Sommige mensen, en daar hoor ik bij, zijn niettemin gebaat bij dwarsliggers. Niets geeft meer impuls aan een streven dan een tegenligger. Mijn dwarsliggers, wetenschappelijk en anderszins, dank ik voor hun bijdrage. Gelukkig maar dat zij toch in de minderheid waren.

Voor de lange, duurzame samenwerking dank ik Gauke Kootstra van de afdeling Heelkunde en Hans van Hooff van de afdeling Nefrologie. Gauke, je bent teruggetreden uit je ziekenhuisfunctie en dus missen we je aanwezigheid bij de wekelijkse patiëntenbeprekingen. I had niet verwacht dat ik je buiten-proportionele optimisme nog eens zou gaan missen. Hans, de vanzelfsprekendheid waarmee wij altijd een beroep op elkaar kunnen doen, waardeer ik in hoge mate. Ik hoop dat we dit nog lange tijd zullen kunnen voortzetten.

Zij die als geen ander weet, wat dit vak betekent en hoeveel plezier je daaraan kunt beleven is Christien Voorter. Christien, ik ken je als een uiterst loyale, betrouwbare en toegewijde collega, die mijn liefde voor dit vak binnen en buiten werktijd deelt. Jouw moleculair biologische inzet, heeft het Maastrichtse laboratorium haar goede naam op dit gebied geleverd. I k hoop nog heel lang met je samen te werken.

Rechtstreeks vanaf de schoolbanken kreeg ik de beste secreta- 
resse, die iemand zich kan wensen, Diana van Bakel. Diana, je hebt je in de afgelopen 15 jaar ontwikkeld van secretaresse tot systeembeheerder, maar vooral tot mijn rechter- en linkerhand. Zonder jou zou ik mijn vele functies onmogelijk kunnen waarmaken. I $\mathrm{k}$ ben je zeer dankbaar voor alles wat je mij uit handen neemt en hoop nog heel lang met je in dezelfde harmonie samen te werken.

De medewerkers van het laboratorium Weefseltypering, en ik noem ze in alfabetische volgorde, Christel, Désiré, Els, Eva, Hilde, Judith, Lisette, Marjan, Melanie, Meriam, Sandra, Sarah, Wendy en Wen, dank ik voor hun grote inzet. Mede dankzij jullie enthousiasme en technische kwaliteiten sta ik hier nu. Jullie zijn een goed en toegewijd team, waar ik graag mee verder ga en nog heel veel van verwacht.

Mijn vader mocht deze dag niet meer meemaken. Gelukkig heb ik hem, de laatste keer dat ik hem zag, nog wel van het voornemen tot deze benoeming op de hoogte kunnen stellen.

Tot slot Werner en Charlotte, jullie zijn en blijven het enig werkelijk belangrijke in dit leven. Werner, jouw relativerend vermogen en onderkoelde humor maken dat ik er het leven bij houd.

Charlotte, zonder jou had deze benoeming minder glans. Ik ben er trots op dat je al je doctoraaltentamens inmiddels hebt afgerond, maar zo mogelijk nog trotser dat je recent je eerste PCR tot een goed einde hebt gebracht.

Ik heb gezegd. 